\title{
Pertanggungjawaban Pidana terhadap Pemilik Tempat Hiburan Malam Atas Peredaran Narkotika di Kota Jambi
}

\author{
Sumaidi \\ Fakultas Hukum Universitas Batanghari \\ Jalan Slamet Riyadi Broni Kota Jambi Telp: (0741) 65351 \\ Correspondence email: sumaidi.medi1966@gmail.com
}

\begin{abstract}
Abstrak : Mengenai peredaran Narkotika di tempat hiburan malam diatur dalam Pasal 35 sampai dengan Pasal 44 UndangUndang 35 Tahun 2009 Tentang Narkotika sehingga penelitian ini bertujuan untuk mengetahui pertanggungjawaban pidana terhadap pemilik tempat hiburan malam atas peredaran narkotika khususnya di wilayah Kota Jambi dan menjelaskan upaya yang dilakukan untuk menanggulangi terjadinya peredaran narkotika ditempat-tempat hiburan malam di wilayah Kota Jambi. Metode dalam penelitian ini yaitu yuridis empiris dan ruang lingkup penelitian yang dikaji yaitu peredaran narkotika serta objek yang dikaji adalah tempat hiburan malam di kota Jambi. Bahan yang digunakan yaitu bahan lapangan dan penelitian pustaka. Teknik pengumpulan data yaitu studi dokumen terkait dengan dokumen-dokumen sesuai dengan pokok permasalahan. Teknik analisis dalam penelitian ini yaitu kualitatif. Pertanggungjawaban pidana terhadap pemilik tempat hiburan malam atas peredaran narkotika khususnya di wilayah Kota Jambi belum diterapkan sehingga upaya yang dilakukan yakni pihak Kepolisian Resort Kota Jambi dengan Badan Narkotika Provinsi dan Badan Narkotika Nasional harus melakukan razia kepada para pengunjung dan pekerja seks komersial, maupun pemilik usaha hiburan malam yang ada di Kota Jambi.
\end{abstract}

Kata Kunci: Pertanggungjawaban Pidana, Hiburan Malam, Narkotika

\begin{abstract}
Regarding the circulation of Narcotics in nightclubs, it is regulated in Article 35 to Article 44 of Law 35 of 2009 concerning Narcotics so that this study aims to determine the criminal responsibility of owners of nightclubs for the distribution of narcotics, especially in the city of Jambi and explain the efforts that conducted to tackle the circulation of narcotics in night entertainment venues in the city of Jambi. The method in this research is juridical empirical and the scope of research studied is the circulation of narcotics and the object studied is a nightclub in the city of Jambi. The materials used are field materials and library research. Data collection techniques, namely document studies related to documents in accordance with the subject matter. The analysis technique in this research is qualitative. Criminal responsibility for the owners of nightclubs for the distribution of narcotics, especially in the Jambi City area has not been implemented so that efforts made, namely the Jambi City Police Resort with the Provincial Narcotics Agency and the National Narcotics Agency must carry out raids on visitors and commercial sex workers, as well as entertainment business owners. night in Jambi City.
\end{abstract}

Keywords: Criminal Liability, Night Entertainment, Narcotics

\section{PENDAHULUAN}

Hukum pidana adalah bagian dari keseluruhan hukum yang berlaku didalam suatu Negara. Hukum pidana itu terdiri dari norma-norma yang berisi keharusan-keharusan dan larangan-larangan yang telah dikaitkan dengan suatu sanksi yang berupa hukuman, yaitu suatu penderitaan yang bersifat khusus. ${ }^{1}$ Oleh karena itu, hukum pidana mengatur terkait dengan norma-norma yang berisikan perintah dan larangan terhadap siapa saja sehingga bagi setiap orang yang melanggar perintah dan larangan yang telah diatur dalam hukum pidana tersebut akan dikenakan sanksi pidana berupa hukuman yang dijatuhkan oleh aparat penegak hukum terhadap pelaku tindak pidana itu sendiri. Dengan dijatuhkannya sanksi pidana itu tidak menutup kemungkinan akan memberikan efek jera terhadap pelakunya sekaligus memberikan pelajaran agar pelaku tindak pidana itu tidak mengulangi perbuatan yang sama di dalam masyarakat.

Untuk itu hukum pidana di Indonesia sangat dibutuhkan karena Indonesia merupakan salah satu negara yang berpotensi sebagai tempat untuk melakukan peredaran narkoba secara ilegal. Dengan adanya hukum pidana ini maka terhadap pelaku tindak pidana narkotika dapat dijatuhkan sesuai dengan sanksi pidana yang terdapat dalam hukum pidana Indonesia dalam hal ini yaitu Undang-Undang Nomor 35 Tahun 2009 Tentang Narkotika. Diadakannya sanksi pidana dalam undang-undang tersebut karena yang menjadi sasaran dalam peredaran narkotika yaitu generasi muda. Apabila generasi muda telah mudah dirusak oleh narkotika maka negara cara yang berada di tangan generasi muda akan menjadi hancur. Tidak hanya generasi muda saja yang menjadi sasaran dari peredaran narkotika itu sendiri, terkadang juga kelas elite seperti pejabat negara tersandung dengan kasus narkotika karena dirinya tidak mampu untuk menahan agar tidak terjerumus ke dalam penyalahgunaan narkotika.

Telah dipahami bahwa banyak generasi muda Indonesia yang gerak kehidupannya cenderung dikuasai dan dikontrol oleh Narkotika yang seharusnya memiliki manfaat yang sangat besar dan bersifat positif apabila

${ }^{1}$ Adami Chazawi. Pelajaran Hukum Pidana 2. Rajawali Pers. Jakarta. 2016, hal.12 
dipergunakan untuk keperluan pengobatan ataupun dibidang pengetahuan, tetapi oleh generasi sekarang Narkotika disalahgunakan dengan berbagai tujuan. Mengenai peredaran Narkotika di tempat hiburan malam diatur dalam Pasal 35 sampai dengan Pasal 44 Undang-Undang Nomor 35 Tahun 2009 Tentang Narkotika. Dalam Pasal 35 UndangUndang Nomor 35 Tahun 2009 Tentang Narkotika, peredaran Narkotika meliputi setiap kegiatan atau serangkaian kegiatan penyaluran atau penyerahan Narkotika, baik dalam rangka perdagangan, bukan perdagangan maupun pemindahtanganan. ${ }^{2}$

Saat ini pemilik tempat-tempat hiburan malam khususnya di wilayah Kota Jambi sehingga hal ini sangat berpotensi terjadinya penyalahgunaan narkotika dan peredarannya pada tempat hiburan malam, seperti tempat hiburan karaoke, diskotik, kafe-kafe, maupun hotel-hotel yang menyediakan tempat hiburan malam, Peredaran Narkotika harus diawasi secara ketat karena saat ini pemanfaatannya banyak digunakan untuk hal-hal yang bersifat negatif. ${ }^{3}$

Berdasarkan uraian di atas, sanksi pidana juga di terapkan terhadap pemilik tempat hiburan malam jika ditemukan peredaran narkotika berdasarkan Undang-Undang Republik Indonesia Nomor 35 Tahun 2009. Untuk itu penulis membuat suatu penelitian ilmiah yang berjudul: "Pertanggungjawaban Pidana Terhadap Pemilik Tempat Hiburan Malam Atas Peredaran Narkotika Di Wilayah Kota Jambi."

Masalah yang diangkat adalah bagaimanakah pertanggungjawaban pidana terhadap pemilik tempat hiburan malam atas peredaran narkotika khususnya di wilayah Kota Jambi dan upaya apakah yang dilakukan untuk menanggulangi terjadinya peredaran narkotika ditempat-tempat hiburan malam di wilayah Kota Jambi.

\section{METODE}

Di dalam penulisan penelitian ini penulis menggunakan metode pendekatan yuridis empiris, dimana penelitiannya dilakukan secara langsung di lapangan. Jadi pendekatan yuridis empiris Dalam penelitian ini yaitu mengkaji secara langsung terkait dengan Pertanggungjawaban pidana yang harus dibebankan kepada pemilik tempat hiburan malam jika terjadi peredaran narkotika. Untuk itu, penelitian ini mengkaji terkait dengan penerapan dan menelaah ketentuan Sanksi Pidana yang terdapat dalam peraturan perundang-undangan yang berlaku, baik yang terdapat dalam KUHP, KUHAP, maupun peraturan-peraturan lain yang terkait dengan pelaksanaan hukum dalam Pertanggungjawaban Pidana Terhadap Pemilik Tempat Hiburan Malam Atas Peredaran Narkotika Di Wilayah Kota Jambi. Ruang lingkup penelitian yang dikaji dalam hal ini yaitu peredaran narkotika di kota Jambi dan objek yang dikaji adalah tempat hiburan malam di kota Jambi.

Bahan yang digunakan untuk mengkaji penelitian ini yaitu bahan lapangan dan penelitian pustaka. Teknik pengumpulan data dalam penelitian ini yaitu studi dokumen di mana mengkaji terkait dengan dokumen-dokumen sesuai dengan pokok permasalahan yaitu pertanggungjawaban pidana terhadap pemilik tempat hiburan malam atas peredaran narkotika di kota Jambi. Teknik analisis yang digunakan dalam penelitian ini yaitu kualitatif. Maksud dari teknik kualitatif yaitu menjelaskan terkait dengan data di dalam penelitian ini dalam bentuk kalimat yang telah tersusun secara sistematis yang akan dituangkan di dalam pembahasan penelitian ini.

\section{HASIL DAN PEMBAHASAN \\ Pertanggungajwaban Pidana Terhadap Pemilik Tempat Hiburan Malam Atas Peredaran Narkotika Di Wilayah Kota Jambi}

Sekarang ini tempat hiburan malam terus berkembang di wilayah hukum Kota Jambi pada setiap tahunnya. Tempat hiburan malam ini berkembang biasanya disebabkan karena banyaknya permintaan dari masyarakat Kota Jambi yang ingin mencari hiburan khususnya generasi muda yang dalam hal ini masih mencari jati dirinya sehingga tidak menutup kemungkinan mereka untuk mencari kesenangan mereka mencari tempat hiburan malam seperti club, karaoke, cafe dan diskotik. Oleh karena itu, tempat hiburan malam ini mendapat izin dari pemerintah setempat yaitu pemerintah kota Jambi sehingga tempat hiburan tersebut menjadi legal di mata hukum. Namun, dengan mendapat izin dari pemerintah setempat dalam hal ini yaitu pemerintah kota Jambi terkait dengan tempat hiburan malam maka dikhawatirkan tempat hiburan malam tersebut sangat rentan terhadap berbagai tindak pidana termasuk juga dalam ini tindak pidana penyalahgunaan maupun peredaran gelap jenis narkotika.

Mengingat banyak bahaya yang ditimbulkan dari adanya tempat hiburan malam ini maka sudah seharusnya pemerintah beserta aparat penegak hukum harus melakukan pemantauan dan razia terhadap setiap yang datang ke tempat karaoke, diskotik dan kafe-kafe guna untuk mencegah agar tidak terjadi peredaran narkotika di tempat tersebut. Apabila terjadi peredaran gelap narkotika di tempat tersebut maka sudah seharusnya terhadap pelaku tindak pidana perdagangan gelap narkotika dan yang memiliki tempat hiburan malam dapat dijatuhkan dengan sanksi pidana karena sesuai dengan prinsip pertanggungjawaban pidana, dimana Siapa saja yang telah melakukan suatu tindak pidana dan menyediakan tempat untuk melakukan suatu tindak pidana maka si pelaku maupun si penyedia tempat tersebut dapat

${ }^{2}$ AR. Sujono dan Bony Daniel. Komentar Dan Pembahasan Undang-Undang Nomor 35 Tahun 2009 Tentang Narkotika. Sinar Grafika, Jakarta. 2011, hal.48

${ }^{3}$ Ibid, hal.49 
dijatuhkan dengan sanksi pidana sesuai dengan aturan hukum yang berlaku. Untuk itu, apabila terjadi tindak pidana peredaran narkotika di tempat hiburan malam tersebut sudah jelas baik pelaku tindak pidana peredaran narkotika maupun pemilik tempat hiburan malam itu dapat dijatuhkan dengan sanksi pidana sesuai dalam Undang-Undang Nomor 35 Tahun 2009 Tentang Narkotika maupun peraturan pelaksana lainnya yang mengatur tentang peredaran gelap narkotika di tempat usahanya.Oleh karena itu, aturan kewajiban pengusaha tempat hiburan secara umum terkait dengan persoalan peredaran narkotika di tempat usahanya dituangkan dalam Peraturan Daerah setempat yang biasa dengan dengan Perda.

Secara pidana, pemilik atau pengusaha tempat hiburan tidak dapat langsung dimintakan Pertanggungjawaban Pidana. Perlu dilakukan penyelidikan dan penyidikan lebih lanjut apakah pengusaha tempat hiburan memang turut terlibat dalam pengedaran gelap narkotika tersebut. Akan tetapi, jika pengusaha melanggar larangan menggunakan usaha hiburan untuk penyalahgunaan narkotika, izin usahanya dapat dicabut. Menurut Pasal 1 angka 6 UndangUndang Nomor 35 Tahun 2009 tentang Narkotika ("Undang-Undang Narkotika") : "Peredaran Gelap Narkotika dan Prekursor Narkotika adalah setiap kegiatan atau serangkaian kegiatan yang dilakukan secara tanpa hak atau melawan hukum yang ditetapkan sebagai tindak pidana Narkotika dan Prekursor Narkotika".

Sebenarnya dalam hal pencegahan dan pemberantasan terkait dengan tindak pidana narkotika itu sudah menjadi kewajiban Lembaga Pemerintah Non Kementerian Badan Nasional Nasional. Lembaga pemerintahan ini telah diatur di dalam Pasal 1 angka 30 Peraturan Pemerintah Nomor 40 Tahun 2013 tentang Pelaksanaan Undang-Undang Nomor 35 Tahun 2009 tentang Narkotika. Untuk itu, dalam hal pencegahan dan pemberantasan terkait dengan tindak pidana narkotika di tempat hiburan malam di kota Jambi menjadi tanggung jawab dalam hal pencegahan dan pemberantasan oleh Badan Narkotika Provinsi/Kota Jambi. Jika Lembaga ini berperan aktif di dalam melakukan pencegahan dan pemberantasan penyalahgunaan dan Peredaran narkotika di kota Jambi maka pengedar di kota Jambi akan mengurungkan niatnya untuk melakukan peredaran narkotika karena jika pengedar tersebut tetap melakukan peredaran narkotika tidak menutup kemungkinan dirinya akan terseret di dalam sanksi pidana yang telah diatur dalam Undang-Undang Nomor 35 Tahun 2009 tentang Narkotika.

Berdasarkan penelusuran penulis terhadap sanksi pidana menurut Undang-Undang Nomor 35 Tahun 2009 tentang Narkotika maupun peraturan pelaksananya tidak mengatur secara khusus soal tanggung jawab hukum pengusaha tempat hiburan malam dalam peredaran gelap narkotika yang dilakukan oleh karyawan maupun pengunjungnya sendiri. Adapun yang diatur khusus dalam Undang-Undang Narkotika adalah sejumlah sanksi pidana bagi mereka yang menjadi calo/perantara dalam transaksi/jual beli narkotika. Pengusaha tempat hiburan tidak dapat serta merta dikatakan sebagai perantara dalam peredaran narkotika tersebut. Perlu ada penyelidikan dan penyidikan lebih lanjut apakah memang pengusaha tempat hiburan terlibat juga sebagai perantara dalam peredaran gelap narkotika tersebut. Aturan lebih lanjut secara umum soal tanggung jawab pengusaha tempat hiburan malam khususnya Di Kota Jambi atas segala kegiatan terjadinya peredaran narkotika di tempat usahanya diatur dalam peraturan daerah, bagaimana peraturan daerah setempat yang mengatur soal peredaran gelap narkotika di tempat hiburan.

Salah satu contoh peraturan daerah yang dimaksud adalah Peraturan Daerah Kota Jambi Nomor 5 Tahun 2013 Tentang Penyelenggaraan Usaha Tempat Hiburan Di Kota Jambi ("Perda Jambi Nomor 5 Tahun 2013"). Dalam Perda ini antara lain diatur soal kewajiban-kewajiban pengusaha tempat hiburan yang disebutkan dalam Pasal 11 ayat (1) Perda Jambi Nomor 5 Tahun 2013 :

a. Memasang tanda dan nomor registarsi izin usaha dari Pemerintah Kota Jambi untuk diketahui oleh khalayak umum.

b. Mengadakan tata buku perusahaan sesuai dengan peraturan perundang-undangan yang berlaku.

c. Menjaga martabat usaha hiburan, serta mencegah penggunaan fasilitas yang disediakan untuk kegiatan yang dapat mengganggu keamanan dan ketertiban umum serta segala hak yang bertentangan dengan kepribadian bangsa dan moral Pancasila.

d. Bertanggung jawab atas sanitasi, kesehatan dan kebersihan lingkungan usaha hiburan dan sesuai dengan peraturan perundang-undangan yang berlaku.

Khusus soal pengedaran narkotika, pengusaha tempat hiburan malam Di Kota Jambi wajib melaporkan kepada kepolisian jika mengetahui adanya peredaran narkoba di tempat usahanya. Hal ini disebut dalam Pasal 11 ayat (6) Perda Jambi Nomor 5 Tahun 2013 yang berbunyi : "Pimpinan atau pengusaha wajib melaporkan kepada Aparat Keamanan (Kepolisian) bila mendapatkan atau mengetahui adanya peredaran dan pemakai Narkoba baik yang dilakukan oleh pengunjung maupun pengelola atau karyawannya sendiri”.

Jika pengusaha tempat hiburan mengetahui bahwa pengunjung dan karyawannya mengedarkan narkotika, akan tetapi pengusaha tersebut tidak melaporkan hal itu ke polisi, dapat dikenakan sanksi administrasi maupun sanksi pidana karena melanggar ketentuan dalam Perda Jambi Nomor 5 Tahun 2013. Adapun contoh kasus dalam hal ini yaitu pemilik salah satu tempat hiburan malam di kawasan Jelutung Kota Jambi berinisial A terjaring Operasi Penyakit Masyarakat yang digelar Polda Jambi Minggu. A kedapatan memiliki senjata api (senpi) dan narkoba jenis 
sabu-sabu. A diamankan setelah petugas kepolisian menemukan benda yang diduga narkotika jenis sabu-sabu serta senjata api. Untuk itu, A diamankan guna pemeriksan di kepolisian. Saat ini yang bersangkutan masih diamankan dan diperiksa serta belum ditetapkan sebagai tersangka. ${ }^{4}$ Dalam hal ini seharusnya kepolisian harus secepatnya menetapkan si A sebagai tersangka karena telah terbukti ditemukan narkoba jenis sabu-sabu.

Jika memang pengusaha tempat hiburan malam tidak bertindak langsung sebagai pelaku, orang yang menyuruh, orang yang turut serta melakukan perbuatan peredaran gelap narkotika tersebut, atau lainnya sebagaimana diatur dalam Pasal 55 ayat (1) KUHP, ia tidak dapat dimintakan tanggungjawab secara pidana atas peredaran tersebut. Pemilik tempat hiburan malam atas peredaran narkotika di wilayah Kota Jambi tempat hiburan tersebut hanya bisa dimintai pertanggungjawaban pidana atas tidak dilaksanakannya kewajibannya sebagai pemilik tempat hiburan, termasuk melaporkan jika ada peredaran narkotika di tempat hiburannya. Ini artinya, tanggung jawab hukum pemilik pengusaha tempat hiburan malam jika mengetahui adanya peredaran gelap narkotika di tempat usahanya itu sebatas pada pelaporan pada aparat kepolisian. Sedangkan tanggung jawab pidana karena pengedaran narkotika tersebut tidak bisa langsung diberikan kepada pengusaha tempat hiburan malam.

\section{Upaya Yang Dilakukan Untuk Menanggulangi Terjadinya Peredaran Narkotika Ditempat-Tempat Hiburan Malam Di Wilayah Kota Jambi}

Upaya yang dilakukan untuk menanggulangi peredaran narkotika di tempat hiburan malam yakni Pihak Kepolisian Di Wilayah Resort Kota Jambi yang besinergitas dengan BNP ( Badan Narkotika Provinsi ) memang sangat rutin turun melakukan razia pada tempat hiburan malam untuk mencegah peredaran narkotika baik di diskotik, cafe, karaoke, hotel hotel yang menyediakan tempat hiburan malam Di Kota Jambi.

Penindakan Pihak Kepolisian Wilayah Resort Kota Jambi yang besinergitas dengan BNP / BNN ( Badan Narkotika Provinsi ), ( Badan Narkotika Nasional ) baik pada para pengunjung dan pekerja seks komersial, maupun pemilik usaha hiburan malam jika tertangkap tangan membawa, menyimpan, mengkomsusi, mengedarkan obat obat'an terlarang dan jenis narkotika, maka akan di proses secara hukum Berdasarkan Undang Undang Narkotika Nomor 35 Tahun 2009 "Peredaran Gelap Narkotika dan Prekursor Narkotika adalah setiap kegiatan atau serangkaian kegiatan yang dilakukan secara tanpa hak atau melawan hukum yang ditetapkan sebagai tindak pidana Narkotika dan Prekursor Narkotika"

Hasil Wawancara Penulis dengan salah satu aparat Penegak Hukum anggota Kepolisian yang bertugas pada Badan Narkotika Nasional Bapak Briptu Nanda Adriansyah yang menjelaskan bahwa upaya penanggulangan Terjadinya Peredaran Narkotika Ditempat-Tempat Hiburan Malam Di Wilayah Kota Jambi terbagi atas dua bagian penting yaitu upaya preventif dan upaya represif. ${ }^{5}$

berikut:

Selanjutnya Penulis akan menjelaskan satu persatu upaya-upaya tersebut agar lebih dipahami, yaitu sebagai

1. Upaya Preventif

Upaya ini merupakan suatu cara penanggulangan yang ditujukan untuk mencegah dan menangkal timbulnya tindakan Peredaran Narkotika Ditempat-Tempat Hiburan Malam Di Wilayah Kota Jambi pertama kali dan usaha ini selalu diutamakan karena seperti yang kita ketahui bahwa lebih baik mencegah dari pada mengobati. Adapun upaya-upaya preventif yang dilakukan oleh pihak Aparat penegak hukum adalah sebagai berikut :

a. Mengadakan penyuluhan tentang bahaya Narkotika. Penyuluhan ini sudah seharusnya dilakukan oleh aparat penegak hukum baik itu Kepolisian, Badan Narkotika Nasional Provinsi dan Kota Jambi. Dilakukan penyuluhan ini bertujuan agar dapat meminimalisir tingkat tindak pidana narkotika di kota Jambi. Itu juga Dengan adanya Penyuluhan tentang bahaya narkotika ini memberikan pemahaman terhadap masyarakat maupun generasi muda sehingga tidak terjerumus di dalam penyalahgunaan narkotika. Oleh karena itu, sudah seharusnya Penyuluhan tentang bahaya narkotika ini dilakukan di tempat-tempat hiburan yang ada di kota Jambi

b. Memberikan kegiatan-kegiatan positif agar mendapatkan kesibukan sehingga mereka bisa terhindar dari Narkotika. Adapun kegiatan-kegiatan positif yang dapat dilakukan masyarakat kota Jambi maupun generasi muda yang ada di kota Jambi seperti melakukan olahraga, penanaman pohon dan kegiatan positif lainnya yang memberikan manfaat kepada masyarakat maupun generasi muda yang ada di kota Jambi. Apabila kegiatan positif yang dilakukan oleh masyarakat maupun generasi muda yang ada di kota Jambi maka secara tidak langsung masyarakat dan generasi muda yang ada di kota Jambi selain terhindar dari penyalahgunaan narkotika juga membentuk kehidupan yang sehat

\footnotetext{
https://www.merdeka.com/peristiwa/kedapatan-punya-sabu-senpi-pemilik-tempat-hiburan-malam-di-jambiditangkap.html, Diakses tanggal 27 Maret 2021.

5 Wawancara Briptu Nanda Adriansyah, Anggota Kepolisian Yang Bertugas Pada Badan Narkotika Nasional. Pada Kamis, 25 Februari 2021 Pukul 10.00 WIB
} 
c. Melakukan patroli keliling pada tempat-tempat yang pernah dijadikan lokasi peredaran narkotika maupun tempat-tempat yang diduga menjadi tempat hiburan malam atas peredaran narkotika khususnya Di Kota Jambi. Adapun tempat hiburan yang ada di kota Jambi seperti Karaoke Djava, Karoeke Yoan, Karaoke Dini, Karaoke Mega dan Diskotik Grand Club. Jika telah dilakukan patroli keliling oleh aparat penegak hukum khususnya kepolisian dari Polda Jambi maka secara tidak langsung akan meminimalisir terjadinya peredaran narkotika di kota Jambi

d. Penempatan Intel anggota kepolisian yang tidak berseragam di tempat- tempat strategis yang memang telah dicurigai sebagai tempat berkumpulnya para pelaku pengedar, maupun pengguna Narkotika.

2. Upaya Represif

Upaya ini merupakan cara penanggulangan secara konsepsional yang ditempuh setelah atau sedang terjadinya peredaran narkotika pada tempat hiburan malam. Adapun upaya represif yang dilakukan pihak aparat penegak hukum sebagai berikut :

a. Melakukan tindakan pengawasan, pengaturan dan pencegahan penyakit yang ditimbulkan karena peredaran narkotika. Tindakan pengawasan terkait dengan peredaran narkotika ini sebenarnya sudah harus dilakukan oleh aparat penegak hukum, baik itu kepolisian maupun Badan Narkotika Nasional khususnya dalam hal ini Badan Narkotika Nasional Provinsi/Kota Jambi. Dengan adanya pengawasan ini tentu dapat meminimalisir tingkat peredaran gelap narkotika yang terjadi di kota Jambi sehingga terhadap pelaku tindak pidana narkotika tersebut dapat dijatuhkan dengan sanksi pidana sesuai dengan isi Undang-Undang Nomor 35 Tahun 2009 tentang Narkotika.

Kemudian tindakan pengaturan dilakukan oleh badan legislatif guna untuk memperkuat aturan hukum terkait dengan peredaran gelap narkotika sehingga apabila terjadi tindak pidana narkotika terhadap pelakunya dapat dikenakan dengan sanksi pidana. Hal ini juga sanksi pidana dapat dijatuhkan terhadap pemilik tempat hiburan malam yang ada di kota Jambi jika terdapat peredaran gelap narkotika di tempat hiburannya.

Dalam hal pencegahan penyakit maka sudah seharusnya pemerintah, aparat penegak hukum beserta Badan Narkotika Nasional Provinsi/Kota Jambi harus melakukan kerjasama demi mewujudkan generasi muda yang bersih dan bebas dari peredaran narkotika di kota Jambi. Apabila tindakan pengawasan, pengaturan dan pencegahan peredaran narkotika telah dilakukan oleh pemerintah maupun aparat penegak hukum maka tingkat peredaran narkotika akan turun di kota Jambi.

b. Memberikan saran untuk pemilik usaha agar bersedia bekerjasama untuk memberantas peredaran narkotika pada tempat hiburan malam. Dengan adanya kerjasama antara pemilik tempat hiburan malam dengan aparat penegak hukum dan pemerintah kota Jambi maka peredaran gelap narkotika dapat diberantas. Kerjasama ini sangat penting dalam mewujudkan kota Jambi bebas dari peredaran narkotika karena jika narkotika tidak ada lagi di kota Jambi maka masyarakat dan generasi muda tidak dikhawatirkan lagi akan melakukan penyalahgunaan narkotika.

c. Pihak Kepolisian Resort Kota Jambi melakukan proses penyelidikan kemudian penyidikan terhadap laporan yang masuk mengenai peredaran narkotika pada tempat hiburan malam di Kota Jambi. Penyidikan dan penyelidikan sangat diperlukan oleh Kepolisian Resort Kota Jambi agar dapat memberantas tindak pidana narkotika khususnya terhadap peredaran gelap narkotika yang ada di tempat hiburan di kota Jambi. Oleh karena itu, Kepolisian Resort Kota Jambi mendapatkan informasi terkait dengan adanya peredaran gelap narkotika maka penulisan resep kota Jambi harus segera melakukan penyelidikan dan penyidikan terkait dengan terjadinya kasus peredaran gelap narkotika itu. Apabila penyelidikan dan penyidikan ini dilakukan secara cepat oleh Kepolisian Resort Kota Jambi maka dimungkinkan peredaran gelap narkotika dapat diminimalisir di dalam masyarakat kota Jambi.

\section{SIMPULAN}

1. Mengenai peredaran Narkotika terhadap pemilik tempat hiburan malam khususnya Di Wilayah Kota Jambi yaitu karaoke, diskotik, kafe-kafe, maupun hotel-hotel Di Wilayah Kota Jambi yang menyediakan tempat hiburan malam dalam prinsip pertanggungjawaban pidana, hanya orang yang melakukan tindak pidana yang dapat dipidana. Pada dasarnya Undang-Undang Narkotika maupun peraturan pelaksananya tidak mengatur soal tanggung jawab hukum pemilik tempat hiburan/pengusaha tempat hiburan soal peredaran gelap narkotika di tempat usahanya. Namun, aturan kewajiban pengusaha tempat hiburan secara umum soal peredaran Narkotika di tempat usahanya dituangkan dalam peraturan daerah setempat.

2. Upaya yang dilakukan untuk menanggulangi peredaran narkotika di tempat hiburan malam yakni Pihak Kepolisian Di Wilayah Resort Kota Jambi yang besinergitas dengan BNP (Badan Narkotika Provinsi) memang sangat rutin turun melakukan razia pada tempat hiburan malam untuk mencegah peredaran narkotika baik di diskotik, cafe, karaoke, hotel hotel yang menyediakan tempat hiburan malam Di Kota Jambi. Penindakan Pihak Kepolisian Wilayah Resort Kota Jambi yang besinergitas dengan BNP/BNN (Badan Narkotika Provinsi), (Badan Narkotika 
Nasional) baik pada para pengunjung dan pekerja seks komersial, maupun pemilik usaha hiburan malam jika tertangkap tangan membawa, menyimpan, mengkomsusi, mengedarkan obat obat' an terlarang dan jenis narkotika, maka akan di proses secara hukum Berdasarkan Undang Undang Narkotika Nomor 35 Tahun 2009.

\section{DAFTAR PUSTAKA}

\section{Buku}

Chazawi, Adami, Pelajaran Hukum Pidana 2, (Jakarta : Rajawali Pers), 2016.

Sujono, AR. dan Bony Daniel. Komentar Dan Pembahasan Undang-Undang Nomor 35 Tahun 2009 Tentang Narkotika, (Jakarta : Sinar Grafika), 2011.

\section{Perundang-Undangan}

Undang-Undang Republik Indonesia Nomor 1 Tahun 1946 Tentang Kitab Undang-Undang Hukum Pidana (KUHP) Undang-Undang Republik Indonesia Nomor 8 Tahun 1981 Tentang Kitab Hukum Acara Pidana (KUHAP). Undang-Undang Republik Indonesia Nomor 35 Tahun 2009 tentang Narkotika.

\section{Internet}

https://www.merdeka.com/peristiwa/kedapatan-punya-sabu-senpi-pemilik-tempat-hiburan-malam-di-jambiditangkap.html 